this Committee, and the articles in The New Phytologist on "Vegetation at Home and Abroad", did much to spread an interest in plant ecology which brought together taxonomists, physiologists and anatomists. In 1911 he organized the first International Phytogeographical Excursion to the British Isles. For this he produced a noteworthy book, "Types of British Vegetation". Two years later he took a leading part in the formation of the British Ecological Society, of which he was the first president; during 1916-37 he edited the Society's Journal of Ecology.

During the First World War Tansley undertook work in the Ministry of Munitions, and afterwards he spent a period in Vienna with Prof. Freud. This resulted in his well-known book "The New Psychology", which spread a knowledge of Freud's theories widely in Britain. Afterwards his mind became much occupied with the teaching of botany in schools, and in 1922 he produced an admirable text-book, "Elements of Plant Biology", which had a far-reaching influonce. In 1923 he was president of Section K (Botany) of the British Association, and delivered a very stimulating address on the position of botany at that time, in which he called for a new outlook in the study of plants. In the same year he resigned his university post at Cambridge and for a few years occupied himself with research and writing. His important work with T. F. Chipp on "Aims and Methods in the Study of Vegetation", and his "Practical Plant Ecology" date from this period.

A new phase in his career came in 1927 with his election as Sherardian professor of botany and fellow of Magdalen College at Oxford. Here he did much to stimulate and reorganize the study of botany. He collected around him a group of able young men and restored the old prestige of the department. $\mathrm{He}$ did much to prepare the way for the provision of a new building, though this was not constructed until after the Second World War.

On his retirement from Oxford in 1937 he devoted himself mainly to the completion of his monumental work, "The British Islands and their Vegetation", in which his own wide knowledge and the labours of British ecologists over some thirty years were epitomized. This fine volume, written in the lucid style which characterized all his works, will long remain as a memorial to his influence and enthusiasm; and it gained for him the Gold Medal of the Linnean Society of London. But his energies were still by no means exhausted, and in 1943 he became chairman of a committee to consider nature conservation and nature reserves in post-war Britain. His book, "Our Heritage of Wild Nature", and his addresses on various occasions did much to arouse a conscious. ness of the value to the nation of the preservation of areas inhabited by interesting plants and animals. He took an active part in the plan for helping teachers and students of all kinds to study plants and animals in their natural habitats, becoming president of the Council for the Promotion of Field Studies; he also provided students with "An Introduction to Plant Ecology", and was joint author of "Plant Ecology and the School". His appointment as first chairman of the Nature Conservancy in 1949 was a fitting climax to his efforts for so many years.

Tansley's work was recognized by his election to the Royal Society in 1915, to an honorary fellowship at Trinity College, Cambridge, in 1944, and by the conferment of a knighthood in 1950 .

He will be widely mourned as a leader and a friend.

$$
\text { H. Hamshaw Thomas }
$$

\section{Sir Richard Paget, Bart.}

Sir Richard Arithur Surtees Paget died on October 23 at the age of eighty-six. He was educated at Eton and Magdalen College, Oxford. After qualifying as a barrister and becoming a member of the Inner Temple, he gave valuable services on a number of industrial panels and commissions, where his genial personal qualities fitted him well as a negotiator. The bulk of his life, however, was spent in the cause of science. He loved science and brought the scientific attitude of mind to bear upon problems in many diverse fields-thus he achieved important work and gained distinction in physics, anthropology, architecture, town planning, acoustics, linguistics, speech and several artistic crafts. He was, moreover, of an inventive turn of mind, delighting in novel and unorthodox ways of viewing things, so that it is not surprising that he anticipated by half a century some present-day developments such as the streamline motor-car.

When in 1915 Britain was faced with calamity, he was one of the first to realize the urgency of well. directed scientific research on a national scale; he acted as assistant secretary of Section II of the Admiralty Board of Invention and Research during 1915-18. Not a few of the practical investigations undertaken by the Board during the First World War were the direct result of his foresight, to which tribute was paid on more than one occasion by the late Sir William Bragg, who was in charge of experimental work for the Navy.

Mention must be made of Sir Richard's keen interest in the arts. He was an accomplished musician, being particularly adept at keyboard improvization and composition. Folk music had a great fascination for him and provided an interest which he was ultimately able to link with his later studies on speech and language. Coupled with his inventiveness was a rare manual dexterity leading to skill in scientific experimentation and many forms of practical art ; for example, he excelled in the manufacture of pottery. As recently as June 1954, prior to a Friday Evening Discourse at the Royal Institution, he created intense interest by demonstrating his early models of the action of the vocal apparatus by which he could reproduce consonants and vowels, thereby simulating human speech. Though these models were connected with work done more than forty years ago, they struck the observer most forcibly at once by the elegance of their simplicity and their appropriateness for the purpose in hand. It is good to know that Sir Lawrence Bragg has now received the models for the Royal Institution Museum and will use them in his lectures from time to time.

Perhaps the most outstanding work of Sir Richard Paget was that upon speech and language. His extreme humanitarianism led him to exert himself to the full in the cause of the deaf and dumb. He put much effort into the development of a sign language for their use.

Several glowing appreciations of Sir Richard's scientific work have already appeared in the Press, both at home and overseas. All of them stress his amazing versatility, his originality of outlook, his zest for life and, above all, his great personal charm and humanity. Perhaps, in concluding, I may be permitted to introduce a personal note. When in 1938 I was faced with the task of opening the large new South-West Essex Technical College and School of Art, the extremely diverse problems involved in 
equipping departments of science, engineering, architecture and building, commerce, women's subjects, and not least a school of art, were just such as to appeal to Sir Richard's 'universal' mind. He gave me much practical advice and designed not a few special pieces of equipment for me. He afterwards addressed the students with great success. The building of the College organ also interested him, and at the opening recital he sketched the instrument and the organist. There must be many like myself who cherish memories of his ready, generous and expert counsel and assistance.
H. LOWERY

\section{NEWS and VIEWS}

\section{Dr. Karl Jordan, F.R.S.: Ninety-fourth Birthday Presentation}

Dr. KARL Jordan, the distinguished entomologist, was honoured on his ninety-fourth birthday by the presentation of a jubilee volume at a meeting of the Royal Entomological Society held at the Society's house in Queen's Gate, London, on December 7 . The volume contains a series of essays and scientific papers by entomologists of many countries reflecting the numerous facets of Dr. Jordan's work. The essays include a biography, and reviews of Jordan's work in organizing the International Congresses of Entomology, his work for the organization of zoological nomenclature, his work on fleas, his influence on current concepts of systematies and evolution, his contributions to the systematies of Anthribid beetles and his work on the Lepidoptera. There follow a bibliography listing some 460 items written by Dr. Jordan over a period of seventy years, and twenty scientific papers. Few men can have contributed more to the science of entomology than Dr. Jordan, and it was fitting, and a sign of the high regard in which he is held throughout the world, that the jubilee volume was initiated in the United States. It was Mr. H. K. Clench, of the Carnegie Museum, Pittsburgh, who fired the enthusiasm of friends of Dr. Jordan in the United States, Canada and in Britain, and who was responsible for a large part of the work of assembling the contributions. The Royel Entomological Society of London, of which Dr. Jordan is an Honorary Fellow, undertook the publication of the volume.

\section{Peaceful Uses of Atomic Energy: India and the United Kingdom}

THe United Kingdom Atomic Energy Authority states that discussions between the United Kingdom Atomic Energy Authority and the Indian Department of Atomic Energy have led to the conclusion of an agreement which ensures that there shall be close co-operation and mutual assistance between the Authority and the Department in the promotion and development of the peaceful uses of atomic energy. The agreement provides for the Authority and the Department to arrange for members of their staffs to consult and work together on mutually agreed topics. In furtherance of this agreement, the United Kingdom Atomic Energy Authority will provide the Indian Department of Atomic Energy with enriched uranium fuel elements for a 'swimming pool' reactor now under construction at Bombay. The agreement also includes arrangements for the Authority to assist in the design and construction of a high-flux research reactor which may be built at a later date.

\section{Technical Education in Great Britain}

REPLYING to questions on technical education in the House of Commons on December 13, the Prime
Minister re-affirmed the Government's determination to make a big advance in technical education and said that the Minister of Education would make a further statement shortly on technical colleges. Sir Anthony Eden did not think that appointment of a committee to inquire into all aspects of scientific, technological and technical training or of a Minister for Technical Education would help. He gave no direct reply to questions regarding the position relative to the U.S.S.R., but said that last year about $£ 4.5$ million was spent on improvements in various spheres of technical education. This year $£ 7$ million is being spent and next year $£ 9$ million. No contracts for technical colleges in Britain were placed during 1946-47, but during subsequent years the figures are: $\quad 1948-49, £ 222,000 ; \quad 1950-51, \quad £ 874,000$; $1952-53, £ 3,307,000$; and last year just under $£ 7$ million.

\section{Sea-going Facilities for Naval Scientific Workers}

INCREASING facilities are being granted by the Royal Navy so that scientists, designers and others concerned with the development of new equipment for the Navy can serve afloat and study the problems of those who use their equipment. For some time naval officers have been specially appointed to naval research and development establishments in an endeavour to ensure that civilian officers fully appreciate naval problems, but it is being more and more realized that knowledge and appreciation cannot be fully acquired through the experience of others. Long periods at sea are possible only for a small proportion of those in the Royal Naval Scientific Service engaged on research, design and the production of naval equipment, but many, including draughtsmen, do visit ships for trials and inspections, even if they do not always proceed to sea. During fleet exercises a number of civil officers are embarked in various units of the fleets as observers to study the general problems of operation and weapon efficiency, and there are, of course, members of the Royal Naval Scientific Service attached to the staffs of the Commanders-in-Chief, Home Fleet and Mediterranean Fleet, as fleet scientific advisers. During recent years the amount and complexity of electronic equipment now fitted in ships have increased to such an extent that special efforts are made to enable the designers and producers of this equipment to study at sea the problems of the user and the maintenance staff. During the past eighteen months the fleets have been able to accommodate in various ships, for periods varying between a few days and four or five weeks, about one hundred civil scientific officers engaged in this sort of work; included in this number are staff representatives from Ministry of Supply Establishments, which are responsible for most of the airborne electronic equipment for the Navy, and also designers and engineers of industrial firms engaged on Admiralty work. 